\title{
SUSTAINABLE DEVELOPMENT, EDUCATION FOR SUSTAINABLE DEVELOPMENT AND PHILIPPINE COMMUNITY
}

\author{
Kim Jim F. RABORAR \\ Oas Community College, Calzada, Oas, Albay, Philippines, 4505, e-mail: imoyraborar@yahoo.com
}

\begin{abstract}
Development is an innate manifestation on earth. It is not even surprising that the world has developed tremendously over the past decade considering the development in the previous decades. That is, development precipitates development. Therefore, even though everybody can see what risks it brings to the earth, we cannot simply restrain it. Of course, we cannot restrain it. The bottomline is that we have no choice but to be part of the development and be one of those who assist in the ever spontaneous development by trying to minimize its unwanted effects to the planet and its inhabitantants, the humans.

Even looking at the 'development' from one's own microcosm, we can perceive that as we go through life and gain some of what this world can offer, we produce tons and tons of wastes. These wastes, which are naturally not part of the earth, pollute and disrupt the natural processes of the planet. It is also simple to notice that the fundamental cause of the depletion of the earth's natural resources was definitely proportional to the increase in population and to the development itself. Here lies one of the underlying global problems at hand aside from poverty, hunger, low access to education, and other socio-anthropological issues we have, this is the issue on natural resources depletion. Even to worldleaders from well-developed countries can recognize that they will also be the ones at the receiving end of this problem. It is basic that living organisms rely on their environment or the abiotic factors, to live sustainably.

Considering these problems, the United Nations, with the worldleaders as its composition, has come up with strategies that advocate development while keeping the earth's natural resources from depletion or the earth's natural processes from disruption. This advocacy is called Sustainable Development. Sustainable Development is the development that meets the need of the present generation without compromising the ability of the next generation to meet their own needs. It is, at its core, an advocacy for futurism and the next generation.

Sustainable Development is primarily anchored with the case of the "carrying capacity" of the planet Earth. It was already implied by several natural scientists as well as social scientists that indeed the Planet Earth increasingly finds it hard to sustain the needs of the human races because of overpopulation. These things result to poverty and hunger around the world. On the otherhand, it is increasing implied that most of the Natural Resources of the planet goes to the well-developed countries, leaving the developing and underdeveloped countries with meager resources. This further increases cases of hunger and poverty.

Although it is deceptive that the call for a sustainable development should take its toll on the countries with bigger economy since they consume the most and pollute the most, it is very definite that there should be a much more intensive application in developing countries since we are just about to experience what the rest of the developed countries have already experienced. More importantly, developing countries should advocate Sustainable Development since it is a common knowledge that even if they contribute least to the causes of natural resource depletion and disruption of natural processes, they are the ones who suffer most from the devastating effects of unsustainable development. As citizens of the Republic of the Philippines, we are one of those who suffer most.
\end{abstract}

KEY WORDS: Sustainable Development (SD), Community, Conditional Cash Transfer, Family Development Session, Education for Sustainable Development (ESD), Sustainable Development Goals, ESD in the Schools and Communities

\section{THE EMERGENCE OF STRATEGIES \& RELATED CONCEPTS}

Through the established strategies and concerns by the UN to uphold worldwide sustainable developments, several more concepts have emerged to target important goals. Education For All (EFA) and Primary Health Care (PHC) endeavours are two of the most prominent and successful among them. Aside from these two, Education for Sustainable Development (ESD) was launched to give emphasis on the potential of the Education to be the zone where sustainable development can emerge in a long-term basis. Education in this concept does not solely focus on Literacy and Academe per se but rather on the community education, office trainings and institutional policy improvement.

Above all, the most tangible step done by the UN to uphold development was the priority development strategizing effort most commonly known as the UN Millennium Development Project paving the way to the creation of Millennium Development Goals (MDGs). The Millenium Development Goals were set during the UN Millenium Summit in September 2000 by the world leaders. These are the following: 1) 
Eradicate Extreme Hunger and Poverty; 2) Achieve Universal Primary Education; 3.) Promote Gender Equality and Empower Women; 4.) Reduce Child Mortality; 5) Improve Maternal Health; 6) Combat HIV/ AIDS, Malaria and other Diseases; 7) Ensure Environmental Sustainability; 8) Develop a Global Partnership for Development. These goals, along with the developments it has incurred, which are attached with very satisfying data, have already concluded on 2015.

MDGs were duly replaced by another set of goals directly called Sustainable Development Goals or SDG's. During the UN General Assembly on September 25, 2015, the 193 countries which are members of the UN adopted the 2030 Development Agenda titled Transforming our world: the 2030 Agenda for Sustainable Development. This included the following goals with the expanded descriptions:

1. No Poverty - End poverty in all its forms everywhere

2. Zero Hunger - End hunger, achieve food security and improved nutrition and promote sustainable agriculture

3. Good Health and Well-being - Ensure healthy lives and promote well-being for all at all ages

4. Quality Education - Ensure inclusive and equitable quality education and promote lifelong learning opportunities for all

5. Gender Equality - Achieve gender equality and empower all women and girls

6. Clean Water and Sanitation - Ensure availability and sustainable management of water and sanitation for all

7. Affordable and Clean Energy - Ensure access to affordable, reliable, sustainable and clean energy for all

8. Decent Work and Economic Growth-Promote sustained, inclusive and sustainable economic growth, full and productive employment and decent work for all

9. Industry, Innovation, Infrastructure - Build resilient infrastructure, promote inclusive and sustainable industrialization and foster innovation

10. Reduce Inequalities - Reduce inequality within and among countries

11. Sustainable Cities and Communities - Make cities and human settlements inclusive, safe, resilient and sustainable

12. Responsible Consumption, Production - Ensure sustainable consumption and production patterns

13. Climate Action - Take urgent action to combat climate change and its impacts

14. Life Below Water - Conserve and sustainably use the oceans, seas and marine resources for sustainable development

15. Life on Land - Protect, restore and promote sustainable use of terrestrial ecosystems, sustainably manage forests, combat desertification, and halt and reverse land degradation and halt biodiversity loss

16. Peace, Justice and Strong Institutions - Promote peaceful and inclusive societies for sustainable development, provide access to justice for all and build effective, accountable and inclusive institutions at all levels

17. Partnerships for the Goals - Strengthen the means of implementation and revitalize the global partnership for sustainable development

\section{THE SD \& ESD IN THE PHILIPPINES}

In 1987, following the United Nations' initiative on the same year, the Department of Environment and Natural Resources (DENR) has initiated the process of Formulating a Philippine Strategy for Sustainable Development (PSSD). Series of consultations and national workshops were conducted to form the Philippine Strategy for Sustainable Development. Finally, on November 29, 1989, the Cabinet passed Cabinet Resolution No. 37 approving the its Conceptual Framework while subjecting it to some modifications which were basically focusing on the protection of the environment and natural resources. Below is the outline of the said document from www.psdn.org.ph/agenda21/pssd.htm:

1. RATIONALE: THE ECOLOGICAL IMPERATIVES IN THE PHILIPPINE CONTEXT

- Population Pressure

- Economic Costs

- Cost to the Ecosystem

2. THE PHILIPPINE STRATEGY FOR SUSTAINABLE DEVELOPMENT (PSSD): THE CONCEPTUAL FRAMEWORK

2.1. GOAL AND OBJECTIVES

2.2. GUIDING PRINCIPLES

2.3. GENERAL STRATEGIES

- Integration of Environmental Consideration in Decision Making

- Proper Pricing of Natural Resources

- Property Rights Reform

- Establishment of an Integral Protected Areas System

- Rehabilitation of Degraded Ecosystems

- Strengthening of Residuals Management in Industry (Pollution Control)

- Integration of Population Concerns and Social Welfare in Development Planning

- Inducing Growth in the Rural Areas

- Promotion of Environmental Education

- Strengthening of Citizens' Participation and Constituency Building

3. ASSESSMENT OF MAJOR ASPECTS

3.1. POPULATION

3.2. ENVIRONMENT AND NATURAL RESOURCES

- Forests

- Urban Ecosystems

- Freshwater Ecosystems

- Coastal Resources

- Land and Mineral Resources

3.3. AGRICULTURE

3.4. INDUSTRY

3.5. ENERGY

To tackle the Education for Sustaible Development wholistically, worldwide or on national level, will definitely be an impossible notion. Judging from the way the PSSD Conceptual Framework was done, the vision of Education for Sustaible Deveopment was clearly emphasized. Credit should be given to those who participated in the making of the document. The document seems to focus largely the Environmental aspect as it should be. It even lacks the incorporation in the formal education. Ironically, the reinforcement and application of most of the strategies related with environmental protection side by side with laws related to it was the waterloo of the Education for Sustaible Development in our country.

Generally, the concept of Sustaible Development has been incorporated on our current practices. A former boss, a government office administrator, has even shared to the athor of this journal that Sustainable Development is one of the most prevailing and ever fundamental topic during large 
conventions. It has also been a basis in policy improvement efforts and decision making bouts in government institutions. The same scenario also applies to CSO's and NGO's. One perfect example is the advocacy of "paperless documentation" where accomplishment reports and other reports were being encouraged to be submitted online as a soft copy rather than submitting hard copies. Unfortunately this practice can only apply minimally since hard copies were needed mostly for auditing purposes.

Judging from the budget allocation and efforts being exerted by our government, it is just right to focus on achieving the Millenium Development Goals, now Sustainable Development Goals, by reaching out to the poor themselves before fretting on anything else. The Philippine Conditional Cash Transfer (CCT) Program of Department of Social Welfare and Development (DSWD) has proven to improve country's development rates based on the criteria set by the various international evaluating committees. Even the famous economist, Provincial Governor of Albay, Joey Salceda, have once quoted during a consultation meeting with the Municipal Links of Albay last March 2012 "Pinirit pirit ko talaga si Director Tapispisan na rugangan kading mga beneficiary idi sa Albay ta magayon kan epekto sa Ekonomiya. Kumbaga, nagiwag sya" (I really kept on requesting Director Tapispisan \{Former DSWD ROV Director\} to increase the number of beneficiaries here in Albay because it does good to the economy. In other words, economy moves.). The Conditional Cash Transfer Program was actually patterned with the various similar platforms across the globe like Mexico and other Latin American nations. In an article regarding economy, the Philippines alongside with Mexico, were pinpointed for economy growth. The program was actually being praised around the world for it's unique salient feature called the Family Development Sessions (FDS).

In our country, social-anthropological problems and issues were particularly being unriddled through several various awareness campaigns. One great example is the RPM or Responsible Parenthood Movement, a joint effort of Local Health Offices and Population Commission. In Responsible Parenthood Movement, Health Officers, primarily public health nurses conduct a half-day seminar for the community people, usually mothers, discussing Parenting Education, Reproductive Health, and Family Planning Methods. Health offices conducting RPMs target yearly seminars to each barangays depending on their population. Along with the above mentioned main topics, RPM's also become the venue for the Health Officers to advocate their services and talk about issues regarding their services. Having attended and conducted several RPM's, the author could say that the program was a potent effort capturing the whole range of ESD based on the three pillars of sustainable development Economic-SocialEnvironmental facets:

- Economic Principles - RPM captures the microcosm of economy in a family unit as it discusses parental responsibilities in a social and legal basis. One common quote during seminars: "Ang responsableng magulang ay ibinibigay ng maayos ang mga pangunahing pangangailangan ng kanyang mga anak tulad ng MALINIS na pananamit, MAAYOS na tahanan, MASUSTANSYANG Pagkain at edukasyon. Kaya dapat mag-aanak lang tayo ng kaya nating suportahan." (Responsible parents provides their children with their basic needs including clean clothing, homely shelter and nutritious food and education. So, we should make sure that we can support our children.)

- Environmental Principles- The local statistics (in Legazpi City, Albay, Philippines) shows decrease in number of births/year/population or crude birth rate (CBR). A control in population is a control in poverty, hunger and unnecessary resource depletion.

- Social Principles- RPM also addresses several home issues like gender inequality and abuse. Another common quote during seminars: "Ang pagpaplano ng pamilya ay parehong resposibilidad ng Nanay at ng Tatay" (Family planning is a joint responsibility of the mother and the father.)

\section{THE FAMILY DEVELOPMENT SESSION AND ITS POTENTIAL}

Most recently, RPM was incorporated in the Family Development Sessions (FDS) being conducted/ facilitated by the frontliners of the CCT program with its member beneficiaries as participants. FDS attendance is one of the keyresponsibilities required to the grantees of the program. Nonattendance would mean less $500.00 \mathrm{Php}$ from the usual amount they are granted. This actually makes the FDS successful in terms of attendance and maximizing the learning potential of the Parent Groups of 4P's beneficiaries in the communities.

FDS Modules are composed of several sessions capturing the lifelong learning needs of common poor Filipino families with the goal of empowering them to achieve self-sufficiency by the end of 5-year period. Topics range from as simple as home management, financial management, several topics on Family Relationships, Gender Equality, to as diverge as Bio-intensive Gardening, Spiritual Topics, Disaster Risk Reduction Management (DRRM) and etc. As a social worker, the mentioned topics were what the author have facilitated and conducted, seeing its essence in the family development of a common rural Filipino family. The DSWD were even issuing Memos to ensure the facilitation of several topics like DRRM and Gender Equality.

Analyzing the content of FDS Modules can lead to an interpretation that these learning venues were actual manifestations of Education for Sustainable Development as it profoundly affects the lives of millions of youth through learning sessions for the parents. This conclusion is anchored in the idea that the future of our country depends on what the present generation is doing right now to make sure that the next generation will be better than they are so progress will be inevitable. Through FDS', the parents are being encouraged to take a stand on various advocacies and develop their lives so their children would see how important it is to have a good life.

\section{PEOPLE'S INITIATIVE FOR LEARNING AND COMMUNITY DEVELOPMENT}

People's Initiative for Learning and Community Development is a movement that advocates ESD through community education. In an article entitled "Education for Sustainable Development" written in their website www.pilcd.org/index.php, PILCD Executive Director, Ramon G. Mapa, discussed several subjects concerning ESD:

- Disaster Risk Reduction

- Climate Change

- Sustainable Agriculture

- Capacity Development 


\section{- Functional Literacy}

Among these, functional literacy and capacity development was being advocated as important denominators especially in developing countries like ours. Communities should be well armed with functional knowledge regarding disasters and hazards, and should be trained to be sustainable and selfsufficient. Like FDS, PILCD also reaches out to the community to impart functional knowledge.

\section{THE LOOPHOLES TO CONSIDER}

Unfortunately, the major setback in ESD application is the saddening fact that the DENR (Department of Environment Natural Resources) and some local authorities has not made any transparent good output upholding the laws regarding our mega-rich ecosystem. If we may ask the Government, "Seriously, can't you achieve economic development while making sure our mother earth is being taken care of?" Resorts and other business establishments where built practically on the site where the Natural Resources are and more!!

Last year, the 'FAILON NGAYON' show has been making a thorough investigation regarding environmental laws and the efforts being pushed by several environmentalists in Boracay, Boracay being one of the most famous beaches in the world making it a forerunner in the tourism industry. Apparently, the show being haphazardly courageous has lobbied their observations and concerns to the concerned agency questioning the agency's competence having approved business permits and building permits where it is not due. After this, a project was already spearheaded to uphold the law. Recently, the TV programme has revisited Boracay revealing several improvements and arising 'discrepancies' on the on-going project.

Well, some other loopholes on RP's SD were already discussed in our classroom like the following:

- mismanagement of the prices of types of fuels that results to more pollution;

- apparent lower taxes (compared to other countries; Sin Tax) of the products that has detrimental effects on Health

- mitigative engineering that results to unfinished infrastructure activities causing us probably billions and worse cases of industrial blights

- meager development among many sectors like agriculture, education and health care delivery systems

- $\quad$ very high tax accompanied with very low minimum wage creating severe poverty

- Weak Early Education Policies, low support to DayCare Centers and DayCare Workers

- High Corruption Cases in Infrastracture Projects resulting to disposable buildings

- "White Horse" System in the government agencies resulting to low quality public services like low quality education

\section{ESD IN THE FORMAL EDUCATION SYSTEM OF THE PHILIPPINES}

Another setback in Republic of the Philippines's ESD lies in the formal education sector, the Department of Education (DepEd) and the Commission on Higher Education (CHED) . For decades, the world has proven that the K-12 Program is an effective educational system that encourages good economy and international competition (not to mention that most of the OFW's were doing subservient jobs and not professional jobs).
But the government has either ignored it, resisted it or just practically brushed it off. Critiques have basically denounced that if not for the ASEAN 2015, the educational system must have remained the same. Even the incorporation of ESD in the curriculums is basically a late practice.

Aside from it, the much needed increase in the salary of teachers is definitely due and timely if we want quality education since the world has been practically pleading for it. Quality Education is 4th Sustainable Development Goal, replacing the Millenium Development Goal that adresses only the Basic Education among children. Furthermore, there is also the need for more school buildings and facilities like laboratories and libraries which should be state-of-the-art. Recently, the DepEd had to adjust school hours so schools could accommodate the suddenly massive number of enrolees, as a result of the CCT Program. These scenarios basically call for the judicious increase in the budget allocation for the Education sector. For years, scholars have felt left behind and betrayed because of the measly budget allocation.

At this moment, the very first batch of the senior high-school (SHS) students are now set to take their eleventh grade. However, recent newspaper journals have cited several relevant the loopholes in the upcoming educational system. One these is the "late" provision and manifestation of the development plan for the Department of education facilities. These primarily include tabular data representing the number of back-logs when it comes to infrastructures.

The $\mathrm{K}$ to 12 Educational System also brings with it the application of Spiralling Curriculum concept by a prized educational psychologist Jerome C. Brunner. This spiralling curriculum seeks to integrate different branches of natural science, increasing in relative difficulty each level of education until 12th grade. This endeavor also paved the way to making Earth Science an integrative part of the curriculum whereas it is previously not. This Earth Science integration will bring about further exploration of Sustainable Development Issues.

\section{SUSTAINABLE DEVELOPMENT IN OUR COMMUNITIES}

Any post-graduate student, especially those exposed in Sustainable Development as a course subject, have an underlying responsibility to analyze his own community based on the grounds of this concept. The following is my own version of analyzing the development in my own community. This analysis is strategically structured based on what I deem most important for me and the entire community with its people.

The Barangay Mendez is composed of a single-street rural community located in the outskirts of the Municipality of Polangui, Albay, surrounded with rice fields. People's daily consumptions are basically sustained through Sari-sari stores and the primary economy revolves around agriculture. Within the past few years, the Barangay has undergone several developments in different aspects. The following aspects plays big role and have relative implications in the general development of the nation.

\subsection{Education}

Education is one of the most, if not the most important, prevailing factors in the development of the lives of people in any community. Public Schools are simple representations of 
the national government. It is also one of the most neglected area in the development for the last decades.

As a child, I was admitted for kindergarten in a private school in a neighbouring Barangay along with some children privileged enough to be sent by their parents for early education prior to Elementary Education. Back then, the community school just have two classrooms and two DepEd teachers. Each classroom is further divided into two levels that mean one teacher teaches two grade levels simultaneously. So it caters for Grades 1 to 4, a meagre primary education. The pupils then would have to travel again from our Barangay to the neighboring barangay for the rest of elementary and Secondary education. Also, the school does not have Kindergarten and the Barangay Office does not offer a Daycare Center due to some reasons.

Recently, the school is established to cater for the whole elementary educations which include a kindergarten and with 7 teachers. Although they would still have to take their secondary education in the neighboring barangay, it is already a big leap considering quality. The Barangay Office has also been maintaining a Daycare Center (DCC) for quite some time now. More and more Preschool-aged children are being subjected to this early childhood education system since the establishment of Conditional Cash Tranfer in our Barangay. This is because one of the key-responsibilities of the 4P's (CCT) members is to enrol their children to DCC as early as 3 years of age. Noncompliance would result to lower entitlement.

\subsection{Water Supply}

As a child, I have seen my community having a little difficulty in acquiring potable water primarily because of geographical location. Our neighbourhood would have to stroll containers all the way to the northern part of the Barangay just to have drinking water. The long walks and the hours of staying in lines for water was once a routine in our barangay. Ironically, the rest of the town proper would get sufficient supply of drinking water although our barangay was only two barangays away from the source of potable water compared to town proper's five barangay away from the source. This is because of the geographic location of our barangay relative to the town proper.

Recently, the newly elected Barangay Officers have successfully petitioned the problem to the municipal level and the barangay was granted 'larger pipes' making the community 'happy' and satisfied. Now, we don't even have to lift a thing and yet we are having the fresh and potable water sustainably flowing in our sinks and bathrooms. On the other hand, this water supply problem is still a major issue in other barangay all across the province.

\subsection{Transportation System}

Transportation systems largely picture the living conditions of people in any community. For example, among well developed cities, public transporations are primarily consisted of taxis while in rural communities in the philippines, motor tricycles are very prevalent along with jeepneys. As college student, I remember long walks from the neighboring barangay to our house since no tricycle was regularly gracing our previously 'lubak-lubak' street. If I'm lucky enough I would get to pay an extra Php20.00 or get to call my father for a motorbike ride home.
Recently, with the collaborative effort of the tricycle drivers and our Barangay Officers, there has been a set TODA or Tricycle Operators and Drivers Association specifically created to cater for our barangay. Even up to these days, I would still walk side-by-side with students towards the other barangay for a tricycle ride especially during the mornings.

\subsection{Irrigation System}

Irrigation systems especially in the largely agricultural country like ours is very much crucial. Although in my community, this criteria has never been a problem as I remember so well since our family owns rice fileds, in other communities across the province of Albay and even across the country, this is a major issue. During my sustainable development essay writing activity with my students in Earth Science, several of my students have cited irrigation system issues as their communities' problem that should be taken good look into.

As a child, I remember having fun with my childhood friends at the back of our houses and swimming at the irrigation system bordering our backyards from the Rice Fields. Back then, the 2-yard canal flows with fresh water where various species of fishes, crabs and some small fresh-water snakes we call "Aninikid" were simply everywhere. We have always had to be reminded to stay rather in middle and avoid the corners with masses of growing grasses. Children playing with those living things and gawking at those fresh water snakes were simply common scenarios. There has been no problem with the irrigation system that supplies for our rice fields back then but some works to be done in case of storms.

Right now, I can't even remember when was the last time I saw an aninikid. Our naturally flowing backyard irrigation was now cemented and still sustainably supplying for the needs of our rice fields. The Barangay Office has recently been giving efforts on waste management since one of the prevailing issues is that the municipal garbage truck does not even reach our barangay.

\subsection{Peace and Order}

My barangay was used to be tagged by neighboring barangays as "Little Mindanao" since the barangay was famous to several peace and order issues ranging from common neighbour shouting-badmouthing flicks to gang riots and even to murder. I even remember the eventful riot during a barangay's Basketball Recreational Game. Simply put, 'name it, we have it.'

Recently, the peace and order in our little community has settled down. Even badmouthing among neighbourhood has diminished a bit. I know this because we have a Sar-sari Store and we know that Sari-sari stores are considered recreation centres for gossiping among neighborhoods. Thanks to the 'iron-fist' government for early troubleshooting bouts and to the infamous religious efforts of the aging sector of the community that engages the youngsters.

\section{A MUCH NEEDED STANDARD OPERATING PROCEDURE}

By observing the developments discussed above, Political Will can be cited the biggest precursor that has caused the milestones aside from the obvious reason that the development was definitely expected in consideration of the increase in population. And so I totally believe that the government should spearhead or most definitely institutionalize regular conduct of 
ESD seminars or at least lectures among the government agencies, business sector, NGO's and CSO's, and other community leaders starting from the national level to the barangay level. Making it part of the annual event for every sector of the community.

But before that, maybe it would do the DENR good to revisit the PSSD Conceptual Framework with other concerned government agencies and the private sector. It would not be that much also to come up with different types of modules that would suit as the learning materials to various participants of the institutionalized annual lecture-seminars. This endeavour would definitely encourage law reinforcement of the much needed laws to be upheld. Of course, the Department of National Defence (DND) and sub-units should be one of the major participants of this endeavour. I also envision that meeting like this could be grounds to various policy improvements and issue troubleshooting for the society. Most definitely the following are some visions that could be attained:

- By then, maybe the prices of the 'sin goods' would hike to about $200 \%$ from its current price. Then the tax from it would be allocated for environmental efforts. It would likely be subsidized to real CSO's and NGO's who were advocating protection of the Mother Nature or to the barangays that has natural resources in their geographical boundaries.

- By then, maybe there would be TESDA Training Centres for each region or depending on the regions' population.
- By then, prices of diesel and other non-unleaded gasoline would hike and people would be choosing to buy unleaded gasoline instead.

- By then, data banking and most of the documentation procedures would be improved and paperless reporting shall be widely applied. Auditing measures would be regularly done through soft copies.

- By then, further industrial blights would be avoided since infrastructure efforts are thoroughly planned in consideration of ESD.

By then...

\section{REFERENCES}

1. www.psdn.org.ph/agenda21/pssd.htm

2. www.pilcd.org/index.php?option $=$ content\&view $=$ article\&i $\mathrm{d}=91$ : esd\&catid $=39$ : artic

3. www.neda.gov.ph/?p=634

4. www.dailyclimate.org/tdc-newsroom/2013/01/sustainabledevelopment-goals

5. www.un.org/apps/news/story.asp/http $\% 3$ Cspan $\% 20$ class=' pullme'\%3Elt $\% 20$ has $\% 20$ become $\%$

6. http://www.undp.org/content/undp/en/home/sdgoverview. html

7. http://www.ph.undp.org/content/philippines/en/home/mdg overview.html

8. http://www.unmillenniumproject.org/goals/

9. https://sustainabledevelopment.un.org/?menu $=1300$ 